\title{
Geographic Referencing of National Forestry Data
}

\author{
W. C. Moore \& G. M. Bonnor*
}

\begin{abstract}
National summaries of Forest resource data must be improved in quality and quantity, and they must be more location-specific. To meet the last requirement, a simple, consistent, accurate and computer-compatible geographic referencing system is needed. The $10 \mathrm{~km}$ Universal Transverse Mercator (UTM) grid referencing system fills this need. The paper describes the concept and the use of the UTM grid system, and outlines the proposed application to referencing forest resource data in Canada.
\end{abstract}

\section{Résumé}

Il importe d'améliorer la valeur et le nombre des résumés de statistiques concernant les ressources forestières du Canada et de préciser leur origine. Pour répondre à cette dernière exigence, il est nécessaire d'avoir un système de référence géographique logique, précis et adaptable à l'ordinateur. Le système universel de projection transverse de Mercator à $10 \mathrm{~km}$ est tout indiqué. Le concept de cette grille UPM ainsi que les grandes lignes d'un façon d'exprimer les statistiques forestières du Canada sont décrits dans cette communication.

\section{Introduction}

Present information on Canada's forest resources is insufficient to fulfill the various needs of planners and policy makers working at regional or national levels. National forest resource data summaries must be improved in quality and quantity, and be more location-specific in nature (Reed 1978). To meet this challenge, a simple and accurate geographic location referencing system, suitable for computerized summarization of Canada-wide forest resource data, is required.

The internationally recognized Universal Transverse Mercator (UTM) grid system is very suitable for location referencing of forest resource data. UTM grid squares are mostly of equal area, and they are compatible with two-dimensional computer printouts. In addition, the UTM grid is scribed on all Canadian National Topographic Series (NTS) maps of 1:250 000 and 1:50 000 scales (i.e. $10 \mathrm{~km}$ and $1 \mathrm{~km}$ grids respectively), as well as on increasing numbers of provincial base maps. The UTM grid is also easily understood and used.

This paper describes the formation of UTM zones and location referencing within zones. Some basic rules for using the UTM grid are provided, an example of a provincial proposal for UTM maps is given, and an outline of forest resource data summaries using the UTM grid is presented.

\section{UTM Zone Formation}

The UTM grid has been devised to supplement spherical coordinates for quick and convenient, yet accurate, twodimensional map referencing. "Mercator" refers to a complex map projection process that is used to represent protions of a large spherical surface (the earth's surface) on flat papers with a minimum of distortion. It is "Transverse" because the projection is in strips that run north-south across the equator rather than east-west along the equator. It is "Universal" because it potentially covers the whole

*Geographer and Research Scientist, Petawawa National Forestry Institute, Environment Canada, Ottawa, Ontario. K1G $3 Z 6$ world. The southern hemisphere and areas north of $84^{\circ} \mathrm{N}$ latitude (i.e. north of all land area) are not considered in this paper.

UTM zones are formed by projecting six degree longitude strips, starting at the $180^{\circ}$ meridian, onto an imaginary cylinder with its axis on the plane of the equator (Fig. 1). This means projections are made with the cylinder in 60 different positions (i.e. $360^{\circ} / 6^{\circ}$ ). The surface of the cylinder is, in effect, simply rolled out flat to form two-dimensional maps of each of the 60 positions (Fig. 2). The advantage of such narrow strips is that distortions of the earth's surface on maps are small and can be ignored by most map users. *

Each $6^{\circ}$ longitude strip is a UTM ZONE. The zones are numbered from 1 to 60 eastward from the $180^{\circ}$ meridian. Each zone is about $670 \mathrm{~km}$ wide at the equator and about 70 $\mathrm{km}$ wide at $84^{\circ} \mathrm{N}$. Figure 3 shows the UTM zone boundaries in Canada, and lines of equal distance from the equator, on a Lambert Conformal Conic projection map. This is the transformation required for mercator projection information so that maps will all fit together. The effect of the UTM zone boundaries on the use of the UTM grid will be considered later under "'Referencing a Grid Cell".

\section{UTM Grid Formation}

A basic, straight and undistorted $100 \mathrm{~km}(100000 \mathrm{~m})$ grid is superimposed on each UTM zone. Figure 4 shows the upper and lower portions of the northern half of a UTM zone (shaded area) containing the basic $100 \mathrm{~km}$ grid. The zone boundaries (meridians of longitude) converge on a point (the north pole), whereas the UTM grid lines remain a constant distance apart.

The grid cells (squares) formed by the basic $100 \mathrm{~km}$ lines are subdivided by $10 \mathrm{~km}$ lines. The resultant $10 \mathrm{~km}$ grid cells are scribed on all 1:250 000 scale NTS maps. There is an additional subdivision to $1 \mathrm{~km}$ cells on 1:50 000 scale NTS maps. Further subdivisions, down to the $1 \mathrm{~m}$ grid, are possible.

\section{Referencing a Grid Cell}

Each UTM zone has its own grid. The vertical lines of the grid are called Eastings, and they are referenced to an imaginary "zero" line drawn $500 \mathrm{~km}$ west of the central meridian in the zone. Thus, the central meridian has an EASTING value of $500 \mathrm{~km}(500000 \mathrm{~m})$ : there are no negative Easting values. The horizontal lines of the grid are called Northings, and they are referenced to the equator. Thus, the equator has a NORTHING value of $0 \mathrm{~m}$.

A grid cell is referenced by the Easting and Northing values applicable to its south-west (usually lower-left) corner plus, of course, the zone number. The reference numbers are given in the order: Zone-Easting-Northing (ZEN). The ZEN memory aid is emphasized, because the UTM reference number sequence is different than that for Meridian/Township/Range or Latitude/Longitude references.

\footnotetext{
-A Transverse Mercator (TM) system in which the earth's surface is divided into even narrower strips (of $3^{\circ}$ longitude) is also used. The $6^{\circ}$ UTM zones are divided in two to form $3^{\circ}$ TM zones. Grids are formed on the same basis, but the $3^{\circ} \mathrm{TM}$ maps are potentially freer of distortions at larger map scales. The fewer zone boundaries of the $6^{\circ}$ UTM grid is a tradeoff for the proposed national system. The $3^{\circ} \mathrm{TM}$ grid is completely compatible with the $6^{\circ}$ UTM grid at the summary scales of the national forestry resource data proposal.
} 


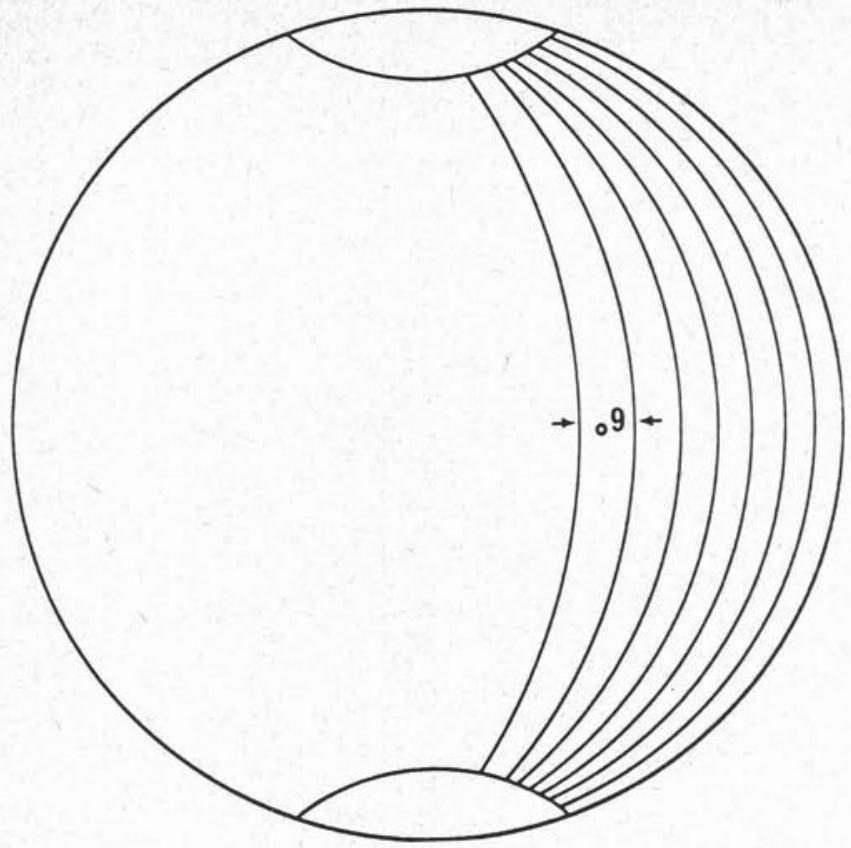

Fig. 1. UTM zones in spherical perspective. (Adapted from Surveys and Mapping Branch 1969, 1971.)

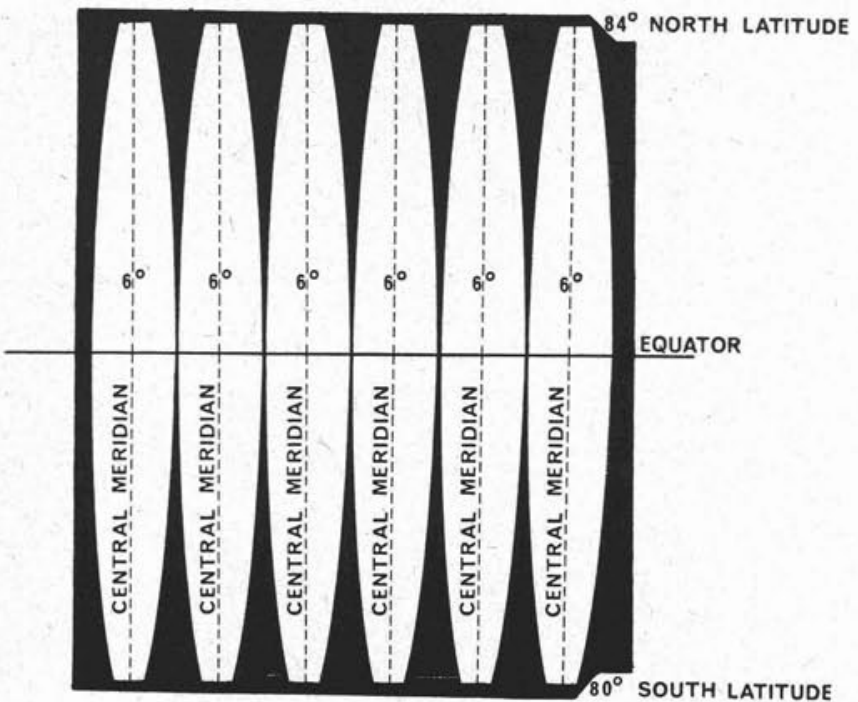

Fig. 2. Adjacent and flattened UTM zones. Longitude strip widths are exaggerated for illustration purposes. (Adapted from Surveys and Mapping Branch 1969, 1971.)

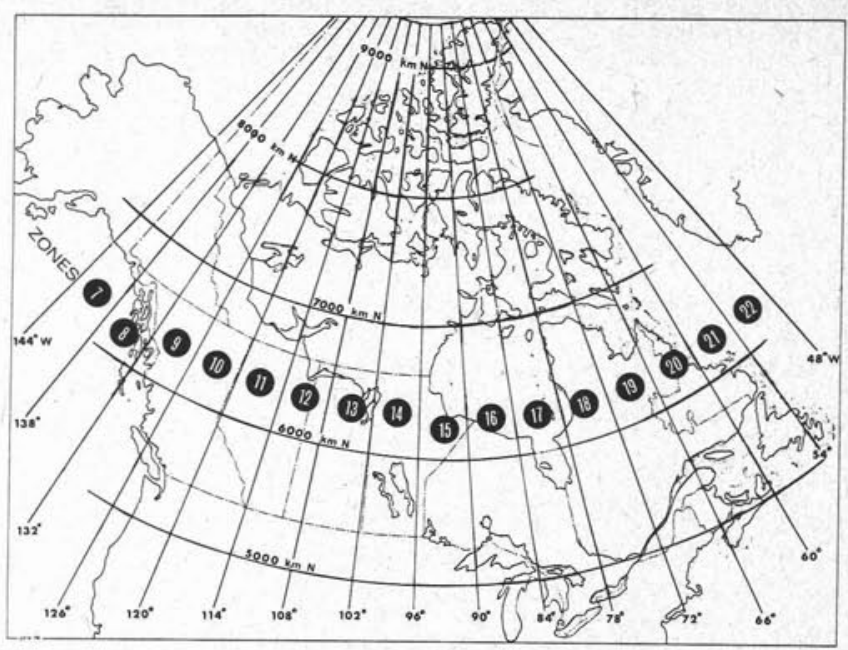

Fig. 3. UTM zones and distances north of the equator for Canada.

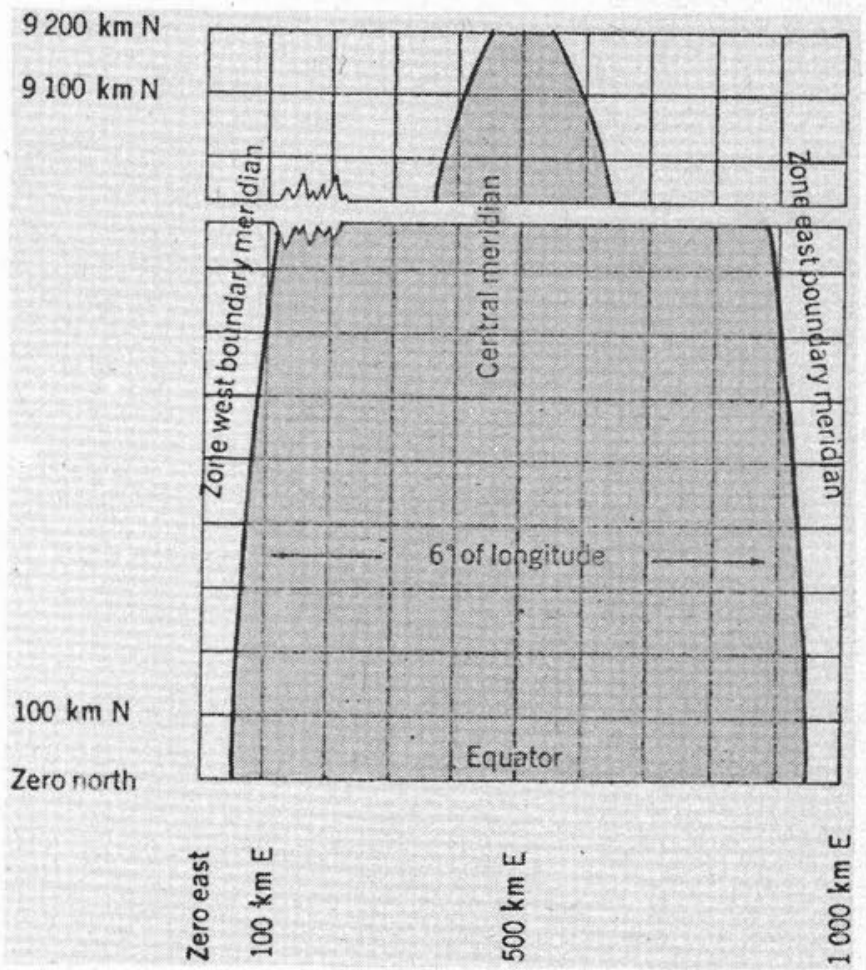

Fig. 4. A UTM zone with basic $100 \mathrm{~km}$ grid. (Adapted from Surveys and Mapping Branch 1969, 1971.)

\section{UTM REFERENCE $14 \quad 21 \quad 589$}

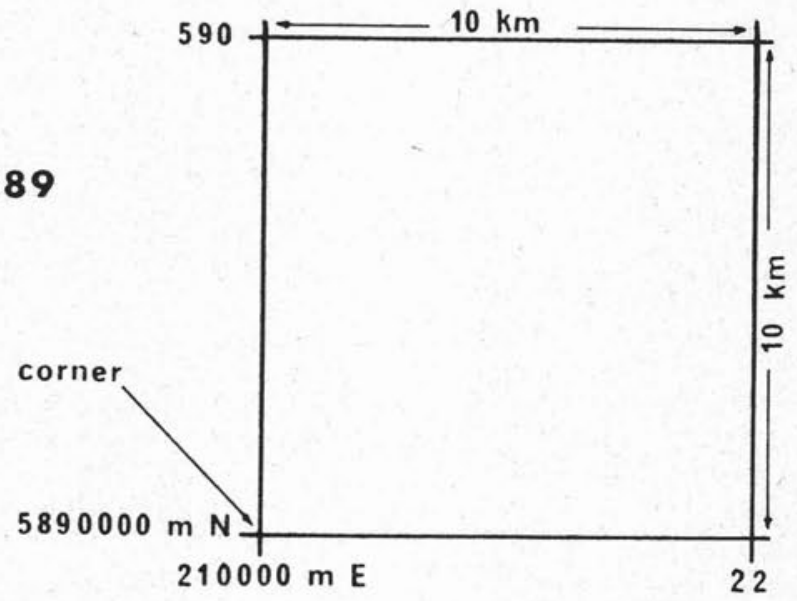

Fig. 5.

Digital reference specifications. The UTM reference number sequence is the same as the convention for " $x$ " and " $y$ " plots on graph paper. The seven-digit reference above is for the whole $100 \mathrm{~km}^{2}$ area of the grid square. 
The size of the grid cell being referenced is determined by the number of digits in the Easting and Northing values. For example, a ZEN number with two Easting and three Northing digits indicates that a $10 \times 10 \mathrm{~km}$ cell is referenced. The trailing zeros are dropped, unless a point reference is intended. Likewise, a ZEN number with three Eastings and four Northings indicates a $1 \times 1 \mathrm{~km}$ grid cell is being referenced, and so on. Figure 5 illustrates the meaning of the ZEN sequence of numbers (i.e. 1421589 ), and Figure 6 illustrates the systematic nature of the UTM grid reference system.

A fifteen digit reference (i.e. 2 for Zone, 6 for Eastings and 7 for Northings) is required for a $1 \times 1 \mathrm{~m}$ square reference. This is equivalent to a point reference at most mapping scales anywhere in Canada. For example, a ZEN number of 142158255895510 might be used to identify the location of

14

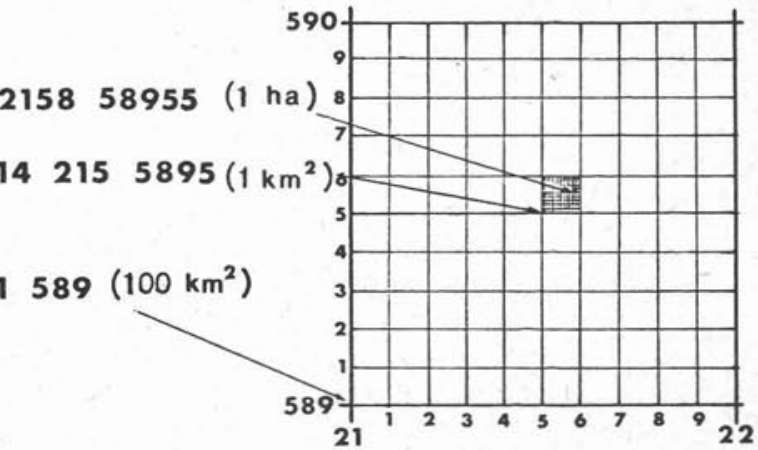

Fig. 6. Referencing grid cells of different sizes. Each digit added to Eastings and Northings (in concert) reduces linear dimensions by a factor of 10 , and areas by a factor of 100 . a tree in the hectare reference in Figure 6.

On zone boundaries, grid cells of less than full size will occur (Fig. 4 and 7). However, the same referencing principle applies. The grid cell (partial) will be referenced to the imaginary (western boundary) south-west corner (Fig. 7).

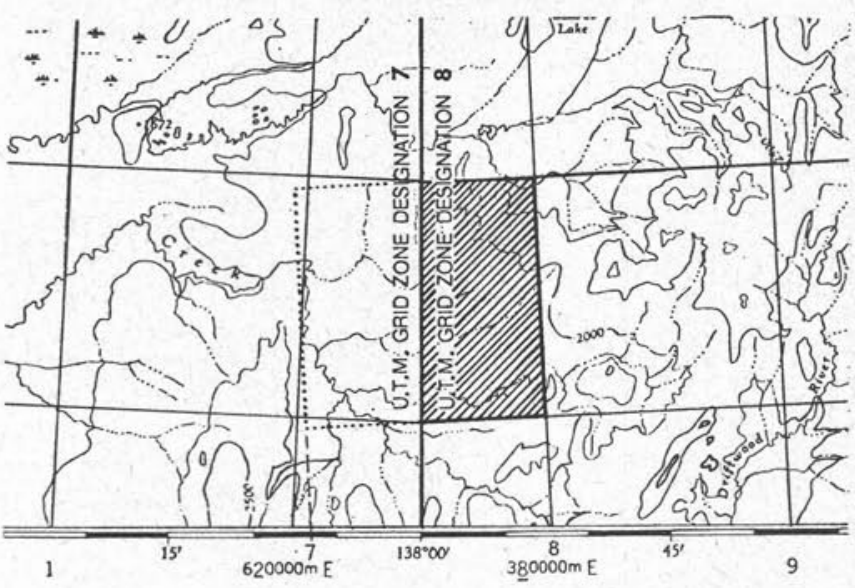

Fig. 7. Mapped UTM grid zone boundary. The southwest corner of each $10 \mathrm{~km}$ grid square for each zone is reference for the whole square - whether or not the square is complete and whether or not the south-west corner is actually mapped. The area of such portions of squares on the ground is less than the normal $100 \mathrm{~km}^{2}$.
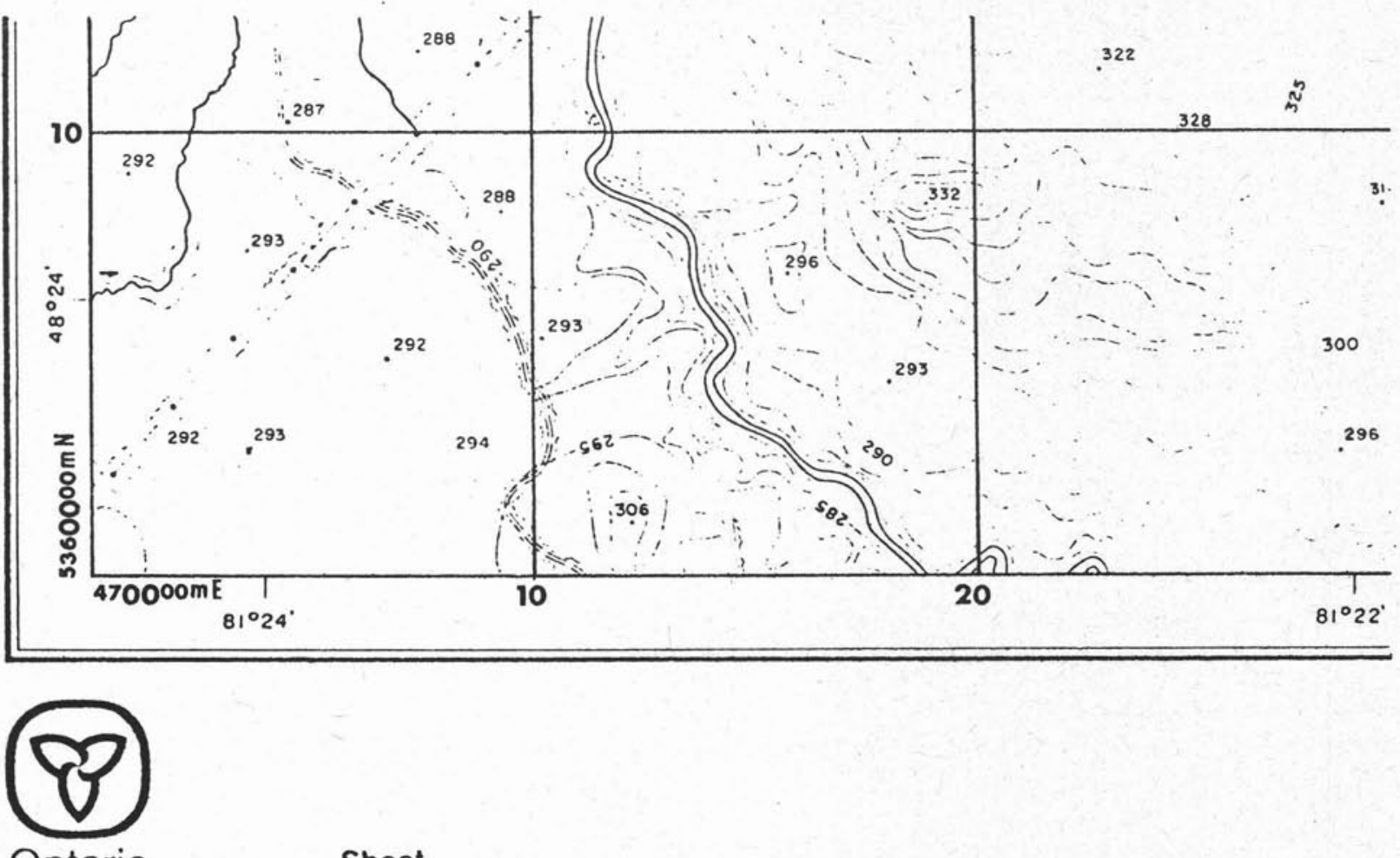

Ministry of

Natural

Resources

Sheet

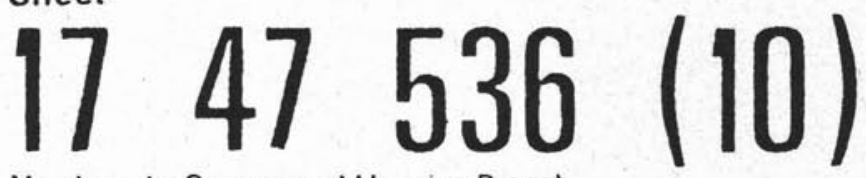

Map base by Surveys and Mapping Branch Air photography 1974. Published 1978.

Fig. 8. Southwest corner of $10 \mathrm{~km}$ Ontario base map. 


\section{Summary of UTM Grid Cell Referencing Rules}

\section{ZEN number sequence.}

Significant digits must be grouped in the following sequence:

Zone Easting

Northing
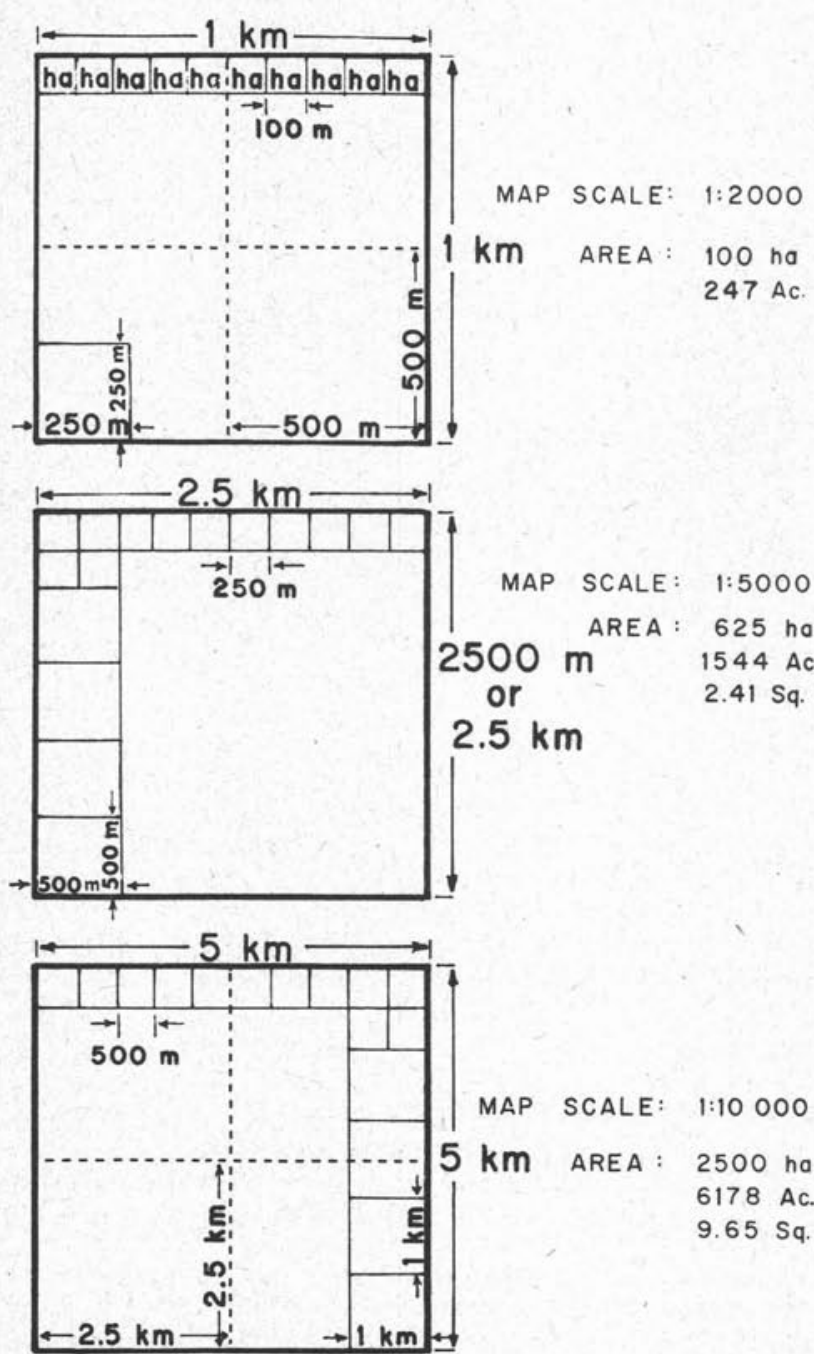

SCALE: $\quad 1: 10000$

AREA :

2500 ho

6178 Ac.

$9.65 \mathrm{Sq} . \mathrm{Mi}$.

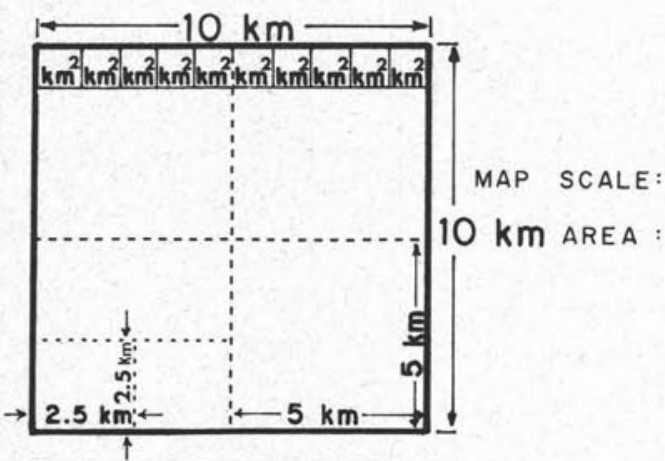

$1: 20000$

10000 ho $100 \mathrm{~km}^{2}$ 24711 Ac. $38.61 \mathrm{Sq} . \mathrm{Mi}$

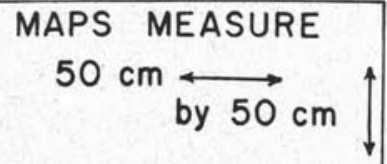

Fig. 9. Ontario basic map series - based on UTM grid. Every map-face above is a convenient desk-top size of $50 \mathrm{~cm}$ by $50 \mathrm{~cm}$. This has been achieved through the use of a rational map-scale series (i.e. submultiples of the $1,2,5$ number sequence).

\section{South-west corner reference.}

All UTM references are to the south-west corner of the grid cell, whether it is a $1 \times 1 \mathrm{~m}$ or $100 \times 100 \mathrm{~km}$ grid.

\section{Number of reference digits determines grid cell size.}

While two digits are always allotted to the zone number, the number of digits in Eastings and Northings (always one more in Northings than Eastings) determines the grid cell size. There are seven digits in the $10 \times 10 \mathrm{KM}$ grid cell reference number - two for Zone, two for Eastings and three for Northings. Likewise, there are fifteen digits in a $1 \mathrm{~m}$ grid cell (or point) reference number.

\section{Application to Regional and Provincial Planning}

The UTM system is a very effective reference tool in mapping not only on the national level, but also on the provincial and regional levels. The Provinces of Alberta, British Columbia and Ontario are already implementing, or are planning to implement, the UTM grid referencing system. The Ontario Ministry of Natural Resources' proposal (Task Force report, 1974 ) is used here to illustrate how the UTM grid referencing system is an efficient and functional working tool.

Compared to national needs, provincial requirements are for more detailed references. The UTM grid system is suitable for both purposes. For example, Ontario Base Map (OBM) sheets are being produced that precisely cover the $10 \mathrm{~km}$ UTM grid squares that are being recommended as summary units in the national program (more later). The 10 $\mathrm{km}$ OBM sheets are being produced for Northern Ontario, and a sample $10 \mathrm{~km}$ OBM sheet reference is contained in Figure 8 . This reference is a $10 \mathrm{~km}$ UTM grid square reference plus the dimension, on the ground, of one side of the map sheet in parentheses. Smaller areas, of course, can thereby be systematically referenced within the map sheet by simply adding digits to Eastings and Northings in concert. In Southern Ontario, $5 \mathrm{~km}$ grid maps (at twice the scale) are used. Four such $5 \mathrm{~km}$ OBM maps are required to cover the same area as one $10 \mathrm{~km}$ OBM sheet. Examples of various measurements on four types of OBM sheets are contained in Table 1. Figure 9 is an illustration of a series of UTM grid cell maps (OBM) at different scales and area of coverage.

\section{Application to Forestry Statistics}

The proposed Canadian Forest Resource Data System (CFRDS) will provide detailed, location-specific data summaries and thematic maps of forest resources for all of Canada (Bonnor 1979). Provincial forest inventories will be the principal sources of the data being compiled. These forestry data will be summarized by grid cell or summary units. These cells, of known area and with mapped boundaries, will completely cover the country. It is planned to develop CFRDS in three phases.

The first phase, a pilot study in the Province of Saskatchewan, is now complete (Bonnor 1978). Forest resource data, from basically the entire commercial forest area of Saskatchewan (about $250000 \mathrm{~km}^{2}$ ), were summarized using a new area-based classification system. A mini-computer system was used for the storage and retrieval of summary data from the resulting data base. These summary data will be supplemented for areas where insufficient provincial information exists with Canada Land Inventory data (Bonnor 1979) and Landsat reconnaissance data (Kalensky et al 1979).

The second phase will be an extension to other provinces to complete the National System. Existing provincial summary units and data will be used where provincial inventory data are available. In areas not presently covered by detailed inventories, a standard summary cell size, the $10 \mathrm{~km}$ UTM grid cells outlined by the blue lines on all 1:250 000 
Table 1: Ontario Ministry of Natural Resources UTM grid map series

\begin{tabular}{|c|c|c|c|c|c|c|}
\hline OBM & Coverage & Area & Area & Area & Area & Area \\
\hline Map-Scales & Dimensions & $\mathrm{km}^{2}$ & ha & acres & sq. $\mathrm{mi}$. & per $\mathrm{cm}^{2}$ \\
\hline 1: $2000^{\star}$ & $1.0 \mathrm{~km} \times 1.0 \mathrm{~km}$ & 1.00 & 100 & 247 & & $400 \mathrm{~m}^{2}$ \\
\hline 1: $5000^{\star \star}$ & $2.5 \mathrm{~km} \times 2.5 \mathrm{~km}$ & 6.25 & 625 & 1544 & 2.41 & $2500 \mathrm{~m}^{2}$ \\
\hline $1: 10000$ & $5.0 \mathrm{~km} \times 5.0 \mathrm{~km}$ & 25.00 & 2500 & 6177 & 9.65 & $10000 \mathrm{~m}^{2}$ (1 ha) \\
\hline $1: 20000$ & $10.0 \mathrm{~km} \times 10.0 \mathrm{~km}$ & 100.00 & 10000 & 24711 & 36.61 & 4 ha \\
\hline
\end{tabular}

The dimensions and area on the ground represented by each $50 \times 50 \mathrm{~cm}$ map sheet are indicated above. The simplification and streamlin ing of data interpretation and handling possible through the use of the metric system of measurements and rational map-scale progressions should also be apparent above.

* by special order only

$\star \star$ for urban areas

\begin{tabular}{|c|c|c|c|}
\hline \multicolumn{4}{|c|}{$\begin{array}{l}\text { Table 2: Provincial forest land by cell } \\
\text { (hypothetical example) }\end{array}$} \\
\hline \multirow[t]{2}{*}{ Cell No.* } & \multirow{2}{*}{$\begin{array}{c}\text { Total Area } \\
\left(\mathrm{km}^{2}\right)\end{array}$} & \multicolumn{2}{|c|}{ Forest land } \\
\hline & & $\mathrm{km}^{2}$ & $\%$ of Total \\
\hline 1334665 & 100 & 56 & 56 \\
\hline 1335665 & 100 & 59 & 59 \\
\hline$\bullet$ & $\bullet$ & $\bullet$ & $\bullet$ \\
\hline$\bullet$ & $\bullet$ & $\bullet$ & $\bullet$ \\
\hline 1334676 & 100 & 100 & 100 \\
\hline 1335676 & 100 & 77 & 77 \\
\hline 1336676 & 100 & 58 & 58 \\
\hline 1337676 & 100 & 47 & 47 \\
\hline$\bullet$ & $\bullet$ & • & • \\
\hline$\bullet$ & • & $\bullet$ & $\bullet$ \\
\hline 1350687 & 34 & 13 & 38 \\
\hline 1351687 & 8 & 4 & 50 \\
\hline
\end{tabular}

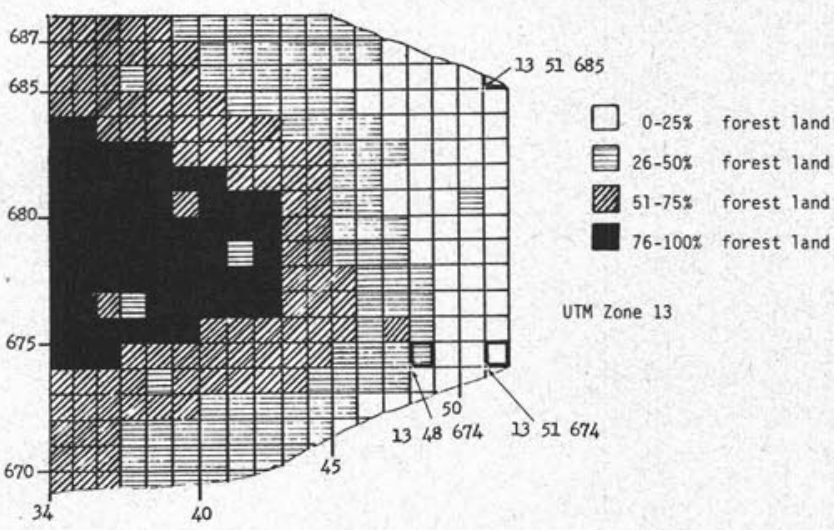

Fig. 10. Portion of map printout - per cent forested land by cell.

capability is critical for forest resource data compilation and summary on a national scale.

\section{References}

Bonnor, G. M. 1978. Pilot study for Canadian forest resource data system. For. Manage. Inst. Inf. Rep. FMR-X-122. Ottawa.

Bonnor, G. M. 1979. National forest statistics in Canada. Proc. Soc. Am. For./Can. Inst. For. Joint Conven., Oct. 1978, St. Louis (in press).

Kalensky, Z. D., W. C. Moore. A. J. Scott, G. A. Campbell and D. A. Wilson. 1979. Forest statistics by ARIES classification of landsat multispectral images. 13th Int. Symp. Remote Sensing Environ., Ann Arbor, April 23-27. (in press).

Reed, F. L. C. \& Associates Ltd. 1978. Forest management in Canada. Vol. 1. For. Manage. Inst. Rep. FMR-X-102. Ottawa.

Surveys \& Mapping Branch. 1969, 1971. The universal transverse mercator grid. Energy, Mines \& Resour. Can., Ottawa.

The existing UTM location reference system is easy to understand, simple to use, and the survey control base is readily available. It also provides a flexible and systematic area reference capability for the whole country. This
Task Force on Geographical Referencing. 1974. Geographical referencing report 1: proposal for basic mapping. Ont. Minist. Nat. Resour., Toronto. 